A Contested Caribbean Indigeneity 


\section{Critical Caribbean Studies}

Series Editors: Yolanda Martínez-San Miguel, Carter Mathes, and Kathleen López

Editorial Board: Carlos U. Decena, Rutgers University; Alex Dupuy, Wesleyan University; Aisha Khan, New York University; April J. Mayes, Pomona College; Patricia Mohammed, University of West Indies; Martin Munro, Florida State University; F. Nick Nesbitt, Princeton University; Michelle Stephens, Rutgers University;

Deborah Thomas, University of Pennsylvania; Lanny Thompson, University of Puerto Rico

Focused particularly in the twentieth and twenty-first centuries, although attentive to the context of earlier eras, this series encourages interdisciplinary approaches and methods and is open to scholarship in a variety of areas, including anthropology, cultural studies, diaspora and transnational studies, environmental studies, gender and sexuality studies, history, and sociology. The series pays particular attention to the four main research clusters of Critical Caribbean Studies at Rutgers University, where the coeditors serve as members of the executive board: Caribbean Critical Studies Theory and the Disciplines; Archipelagic Studies and Creolization; Caribbean Aesthetics, Poetics, and Politics; and Caribbean Colonialities.

Giselle Anatol, The Things That Fly in the Night: Female Vampires in Literature of the Circum-Caribbean and African Diaspora

Alaí Reyes-Santos, Our Caribbean Kin: Race and Nation in the Neoliberal Antilles

Milagros Ricourt, The Dominican Racial Imaginary: Surveying the Landscape of Race and Nation in Hispaniola

Katherine A. Zien, Sovereign Acts: Performing Race, Space, and Belonging in Panama and the Canal Zone

Frances R. Botkin, Thieving Three-Fingered Jack: Transatlantic Tales of a Jamaican Outlaw, 1780-2015

Melissa A. Johnson, Becoming Creole: Nature and Race in Belize Carlos Garrido Castellano, Beyond Representation in Contemporary Caribbean Art: Space, Politics, and the Public Sphere 
Njelle W. Hamilton, Phonographic Memories: Popular Music and the Contemporary Caribbean Novel

Lia T. Bascomb, In Plenty and in Time of Need: Popular Culture and the Remapping of Barbadian Identity

Aliyah Khan, Far from Mecca: Globalizing the Muslim Caribbean

Rafael Ocasio, Race and Nation in Puerto Rican Folklore: Franz Boas and John Alden Mason in Porto Rico

Ana-Maurine Lara, Streetwalking: LGBTQ Lives and Protest in the Dominican Republic

Anke Birkenmaier, ed., Caribbean Migrations: The Legacies of Colonialism

Sherina Feliciano-Santos, A Contested Caribbean Indigeneity:

Language, Social Practice, and Identity within Puerto Rican Taino Activism 



\section{A Contested \\ Caribbean Indigeneity}

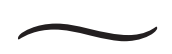

Language, Social Practice, and Identity within Puerto Rican Taíno Activism

SHERINA FELICIANO-SANTOS

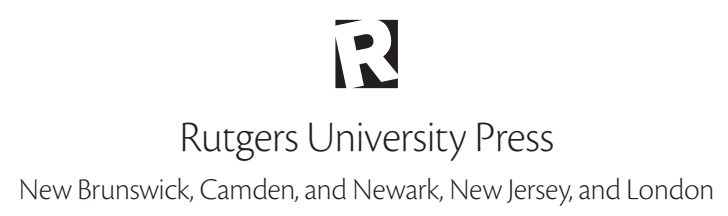




\section{Library of Congress Cataloging-in-Publication Data \\ Names: Feliciano-Santos, Sherina, author.}

Title: A contested Caribbean indigeneity : language, social practice, and identity within Puerto Rico Taíno activism / Sherina Feliciano-Santos.

Description: New Brunswick, NJ : Rutgers University Press, [202I] | Series: Critical

Caribbean studies | Includes bibliographical references and index.

Identifiers: LCCN 2020020793 | ISBN 978197880817I (paperback) alk. paper |

ISBN 9781978808188 (hardcover) alk. paper | ISBN 9781978808195 (epub) |

ISBN 978197880820I (mobi)| ISBN 9781978808218 (pdf)

Subjects: LCSH: Taino Indians-Puerto Rico-Ethnic identity. |

Taino Indians-Puerto Rico-Political activity. | National characteristics, Puerto Rican. | Jíbaro (Puerto Rican identity) | Indian activists-Puerto Rico. |

Ethnicity-Puerto Rico.

Classification: LCC Fr969.F39 202I | DDC 305.80097295-dc23

$\mathrm{LC}$ record available at https://lccn.loc.gov/2020020793

A British Cataloging-in-Publication record for this book is available from the British Library.

\section{Copyright (C) 202I by Sherina Feliciano-Santos}

All rights reserved

No part of this book may be reproduced or utilized in any form or by any means, electronic or mechanical, or by any information storage and retrieval system, without written permission from the publisher. Please contact Rutgers University Press, Io6 Somerset Street, New Brunswick, NJ o890I. The only exception to this prohibition is "fair use" as defined by U.S. copyright law.

(2) The paper used in this publication meets the requirements of the American National Standard for Information Sciences-Permanence of Paper for Printed Library Materials, ANSI Z39.48-I992.

www.rutgersuniversitypress.org

Manufactured in the United States of America 
For all of mis amores from before, now, and the future: Abuelito, Abuelita, Abuela Adela, Mami, Daddy, Allen, Eric, Liza, Zoelle, Jonathan, Mateo, and Isaac. Siempre. 
